\section{Design implementation and authentic assessment of a unit according to Concept- Based Interdisciplinary Approach ${ }^{*}$}

\author{
Yeliz BOLAT ${ }^{a, * *}$ Memet KARAKUŞ ${ }^{b}$
}

\begin{tabular}{|c|c|}
\hline Received: & 11 April 2017 \\
\hline Revised: & 22 June 2017 \\
\hline Accepted: & 02 July 2017 \\
\hline \multicolumn{2}{|c|}{ ISSN: 1307-9298 } \\
\hline \multicolumn{2}{|c|}{ Copyright ( IEJEE } \\
\hline \multicolumn{2}{|c|}{ www.iejee.com } \\
\hline
\end{tabular}

DOI: 10.26822/iejee.2017131885

\begin{abstract}
In this study, students' views on the process of authentic assessment and implementation of a unit which was designed by using conceptbased interdisciplinary approach were examined. To achieve this, the influence of implementation on teaching-learning process and also students' perceptions about authentic assessment were investigated. The study was conducted as a case study which is one of the qualitative research designs. The sampling group was composed of 14 students. Data collected through interviews, observations and journals were analyzed with the help of content analysis method. Results indicate that students thought that the implemented activities were different from the previous ones. These activities made students' interest into lessons to increase and contributed to developing positive attitude and working collaboratively. Students also thought that authentic assessment activities were different from previous ones in terms of being oriented to learning process, being student-centered, requiring metacognitive strategies and usage of information about various disciplines. Interdisciplinary activities and the process of authentic assessment prepared by teachers consciously provided beneficial contributions for students to take responsibility of their learning and for teachers to make more realistic assessment. For this reason, it is useful for teachers to develop their skills in designing interdisciplinary programs and authentic assessment.
\end{abstract}

Keywords: Interdisciplinary instructional design, concept teaching, authentic assessment

\title{
Introduction
}

In today's world, developments in science and technology have made new research and approaches come into existence. These developments make interdisciplinary education obligatory instead of specialized in only one field in order to bring up qualified and eligible individuals. As for education, it is necessary to make regulations which will provide students to learn different disciplines in a harmony and to establish connections between these different disciplines (Demir, 2009). According to Jones (2010), interdisciplinary approach is a technique which is important and challenger for modern education programs. This approach makes a great contribution to synthesizing more than one disciplines and to the development of higher order thinking skills such as creativity, building communication, critical thinking and holistic learning of students and moreover, it provides teachers to work in teams. According to Savage and Drake (2016) emphasize that interdisciplinary approach is an important approach for the 21st century. Head (1997) stated that students were active learners in interdisciplinary teaching. He also pointed out that the curriculum included a rich seam of knowledge which was practical and realistic, and presented authentic integration. Vars (1991) asserted that the integrated curriculum was more effective in academic achievement on the basis of studies conducted about the comparison of traditional and integrated curriculum. Hartzler (2000) reported that interdisciplinary approach was successful in mathematics, social sciences, literature and physical sciences for each grade, and this curriculum was beneficial particularly for students who had a low level of academic achievement.

In some universities which have doctorate programs (Dalhousie, Tufts, Union Universities), interdisciplinary instruction is a field about which is conducted so many studies and is attracting the attention all over the world. Beginning from 2000s, the effect of interdisciplinary and integrated programs upon the curricula developed in our country has started to be seen. In the program of primary school which started to be renewed as of 2005 , a thematic approach has been adopted on the basis of constructivism and by making connections between syllabi, it has been tried to make integration. Integration of social studies course was categorized under three headings which are other courses, between the outcomes of the units and with the sub-disciplines (MEB, 2009). However, in some studies conducted about the current curriculum of social studies, it was determined that there were some deficiencies in constructing outcomes with an interdisciplinary point of view (Keçe \& Merey, 2011, Doğanay, Karakuş \& Bolat, 2013) and interdisciplinary connections built in the process of assessment were insufficient (Doğanay, Karakuş \& Bolat, 2013).

\footnotetext{
* This study is a part of Yeliz Bolat's doctoral dissertation: "An Action Research on Authentic Assessment of a Unit Designed according to Concept-Based Interdisciplinary Approach" supervised by Memet Karakus.

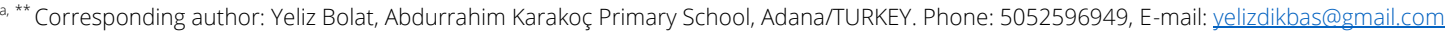

'Çukurova Universtiy, Education Faculty, Adana, TURKEY. E-mail: memkar@cu.edu.tr.
} 
Social studies contain information about many disciplines by its very nature; therefore, students have to learn a great deal of situations, places, dates and phenomena. Doğanay (2008) points out that teaching-learning process of social studies is effective when they are integrated. If topics in social studies are taught with an interdisciplinary approach, if topics intercept in terms of dates and places, if the implementation of instruction, knowledge, skills, values and attitudes are integrated into the life, if technology is effectively used in teaching and if topics in social studies are associated with topics of other courses, the integration is ensured.

The components of education programs are aims, content, teaching-learning processes and assessment. It is necessary to make assessment in order to identify whether there is something wrong or insufficient and if there is any, to define what causes flaws in the program and to make necessary alterations (Demirel, 2011). Assessment informs teachers about teaching process, student' behaviors and success. In the phase of assessment, the most common difficulty is not to be able to make connection between students' success and reallife situations. For this, both teaching process and assessment process should be taken into consideration along with real-life situations concurrently. In this regard, it is essential to reveal how the improvement in students' success is. It is necessary to create real-life situations in which students can improve their metacognitive skills and to observe the improvement in student behaviors in this process (Kutlu, Doğan \& Karakaya, 2010). It can be said that authentic assessment is required in order to carry out this observation.

Authentic assessment is based on the ground of assessment made by students using higher order thinking skills. To achieve this, students need to be an effective practitioner by using knowledge that they acquired (Wiggins, 1990). In authentic assessment, it is not important to understand how much students remember what they learned; rather, it is important to improve the learning process and to understand the qualitative changes in students' prior knowledge (Tynjala, 1999). Wiggins (1990) who compared traditional and authentic assessment stated that assessment based on data which was concretely observed in real-life like situations and obtained with various measurement tools was authentic. To assess out-of-class, empirical and environment-related skills, knowledge and attitudes in the right way, integrated and interdisciplinary programs are focused on and firstly, an appropriate framework for assessment is applied. In most of integrated and interdisciplinary programs, authentic assessment reflecting cognitive, emotional and psychomotor factors has been adopted (Dupe, 2009).

It can be stated that interdisciplinary instruction is needed to bring up individuals who can keep up with the developments in the world, think about different point of views, solve problems by integrating information from different disciplines, transfer what they learn into real-life situations and use them. Explanations above can indicate that interest into this approach in our country has just started. When rarity of implementations based on practice and the fact that the current program does not reflect interdisciplinary approach taken into account, a study that will be conducted about implementing and assessing a unit designed in the light of interdisciplinary approach most probably contribute to the related literature. It is worth investigating students' views on teaching-learning and assessment processes of a unit designed according to interdisciplinary approach based on concepts. In this respect, the aim of the study is to examine students' views on teaching-learning and authentic assessment processes of a unit designed according to interdisciplinary approach based on concepts in social studies course.

Interdisciplinary approach is the conscious integration of related disciplines that can compose of a unit or a theme by connecting a concept or a problem or a topic with more than one discipline. This approach is essential in terms of being beneficial for individuals to perceive the world, to learn information more easily, to influence their academic achievement and their attitude toward the course in a positive way, to improve their cognitive, social and emotional skills and to look at the problems from different point of views. Due to these features, it is believed that the study conducted based on this approach may be fruitful for enriching the instruction, making learning easy and enjoyable, developing positive attitude toward the course and using what is learnt in real-life by connecting the information with real-life.

\section{Method}

\section{Research Design}

In this study which aims at investigating students' views on implementation and authentic assessment of unit designed by using concept-based interdisciplinary approach, case study method which is one of the qualitative research designs was utilized in order to deeply describe, implement and define how students are affected from the relevant situation in the process of assessment. The case was the process of implementation and authentic assessment of a unit designed depending on concept-based interdisciplinary approach. Holistic single case method in which a single unit of analysis was completely dealt with was used so as to understand the processes and changes occurring in the relevant situation. Case study is a research design which investigates a current phenomenon in its own reality and it is used when the border of content of phenomena is not clear or when there are more than one data sources (Yin, 1984, cited in Yıldırım \& Şimşek, 2005). In case studies, more than one data collection tool is used to collect more indepth information (Büyüköztürk, Çakmak, Akgün, Karadeniz \& Demirel, 2009). In holistic single case design, there is a single unit of analysis (an individual, an institution, a program, a school, so on) (Yıldırım \& Şimşek, 2005). In this study, data were collected through journals, interviews and observations in order to see how students' views are affected from the situation.

\section{Participants}

The study was conducted in one of the fourth grade classes of a ministerial primary school located in Seyhan district in Adana. According to the information obtained 
from the school administration, socioeconomic level of students were either medium or under the medium level. The sampling group was defined with the method of criterion sampling which is one of the purposive sampling methods and 7 male and 7 female fourth grade students, in total 14 students, were selected. In the process of defining the sampling group, criteria below were taken into account:

- Permission for using camera and audiorecordings in the study,

- Primary school students who are volunteer to participate in the study,

- A classroom teacher who is willing to participate in the study,

- Administrators who support the study and help to create necessary opportunities for the study,

- A classroom which has required physical conditions (projection, computer, internet and speaker) to conduct the study.

Designing a Unit Appropriate for Interdisciplinary Approach

In the study, to design an interdisciplinary unit, the designing model suggested by Jacobs (2004) was used as a base.

Jacobs (2004) explained seven steps for developing an interdisciplinary curriculum. Before these seven steps, he/she suggested two pre-steps:

Pre-step 1: Assessing student profile: In planning which is the first step, a great deal of and in-depth information about students are collected. Data are collected for students' background, personal development and needs.

Pre-step 2: Assessing the environment: The second step is to evaluate the classroom environment before starting to design interdisciplinary unit. While planning the interdisciplinary unit, environmental factors that can affect instruction should be considered.

1. Selecting a format: The environment where the instruction occurs and students' needs are defined.

2. Defining a title and organizing center: A topic and a theme title which can be suitable for interdisciplinary content, attracting students' interest and can reflect the content is selected.

3. Brainstorming by using concept wheels: For each discipline which is related topic, theme or problem, a concept wheel involving an arm for each discipline is drawn. Brainstorming about each arm of the concept wheel is performed.

4. Developing main questions: Main questions are the total of the things that students need to know and explain in the unit. For an interdisciplinary unit, main questions should provide students to discover the natural connections among disciplines which are defined with students.

5. Integrating skills and assessment with main questions: A compilation is accomplished for the interdisciplinary unit. The content, various disciplines, skills and assessment around the organizing center are combined together.
6. Planning the day-to-day activities: A plan is prepared for activities which will provide students to gain determined skills and to establish connection with each activity related to the defined questions. This plan should present a picture of the relation between main questions and the content, the way how the study serves to develop skills and the way of assessment at the end of the process.

7. Making the final review: All steps are reviewed before starting the implementation.

As for the above two pre-steps and the first step, data about students and the existing situation of the classroom were collected by interviewing the classroom teacher and students. Then, the data about classroom atmosphere were collected by making observation in the unit of "Learning my Past". After evaluating the collected data, we moved to the following step.

In the second step, the concept of environment which is thought to be appropriate for the content was selected as the topic and the name of the unit was defined as "The Environment".

In the third step, concepts and disciplines about the concept of environment put into the center are defined by brainstorming and shown in the concept wheel (Figure 1 and 2).

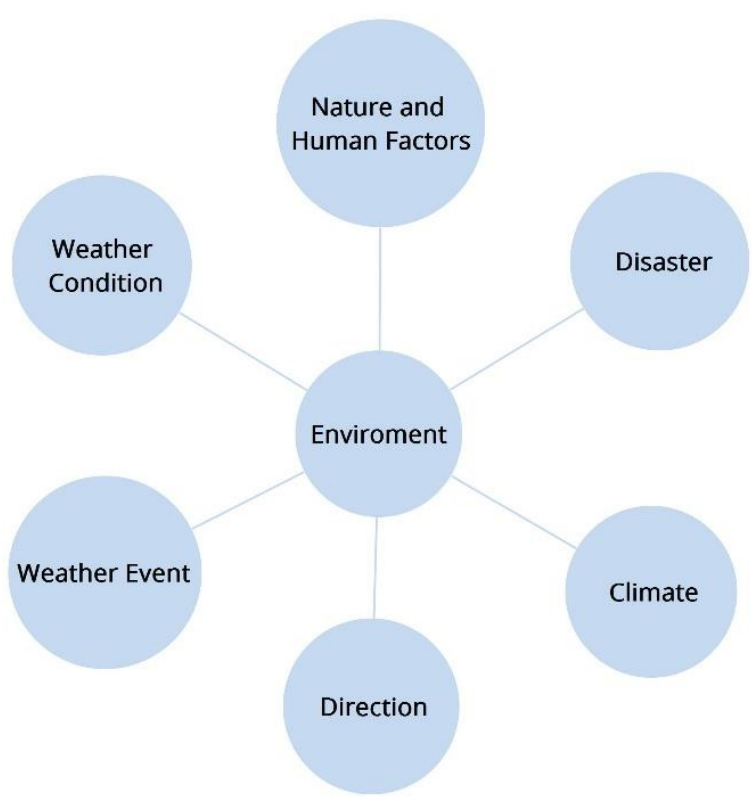

Figure 1. Concept wheel showing concepts related to the concept of environment

After brainstorming, it was decided that the concept of environment was associated with concepts of disaster, climate, weather event, weather condition, direction, nature and human factors.

In Figure 2, it is seen that the concept of environment is associated with social studies, physical sciences, Turkish, mathematics, visual arts, English and music.

In the fourth step, outcomes were written by taking into account questions linked to information gained about the unit of environment by students and the level of concept 
teaching. These studies were presented to the thesis monitoring committee. Outcomes were put into their final forms in the light of views and opinions of the thesis monitoring committee.

In the fifth step, skills and outcomes related to the unit of environment were determined by examining the curricula of physical sciences, Turkish, mathematics, visual arts, English and music.

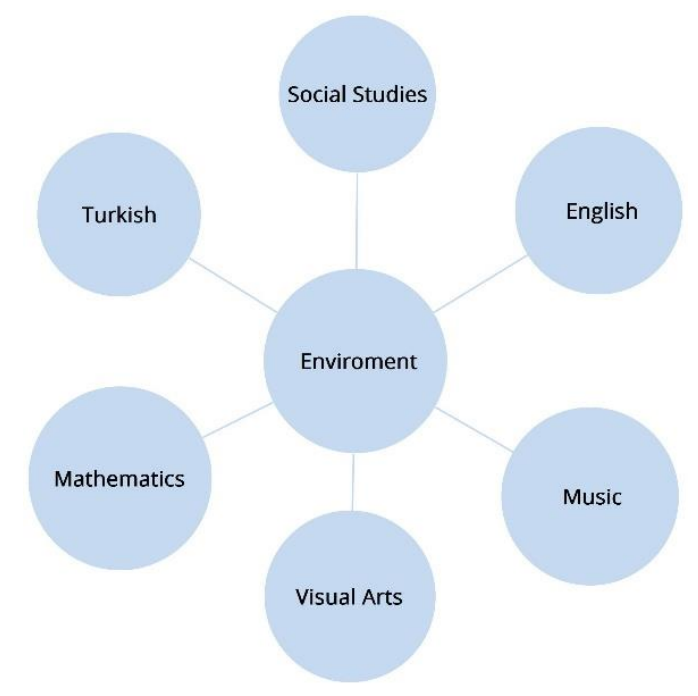

Figure 2. Disciplines related to the concept of environment

In the sixth step, authentic assessment activities suitable for interdisciplinary approach which can provide processbased assessment and syllabi oriented to interdisciplinary connections and to gain the mentioned outcomes and skills were prepared.

As an authentic assessment activity, performance tasks, sematic analysis tables, making classifications and asking classification questions, making models were prepared. These activities were evaluated with rubrics and level identification checklists.

In the last step, for the prepared unit of environment, expert opinion was obtained and it was made ready for implementation.

\section{Data Collection Tools and Analysis}

Data were collected through semi-structured interviews, unstructured observations, and the researcher journal and student journals. Semi-structured interviews prepared for the classroom teacher and the students were designed by the researcher and put into its final version after getting the expert opinion. These forms were composed of open-ended questions. Questions were prepared for three interviews which are preinterview, process-interview and follow-up interview for students. In the pre-interview, there were questions about defining the existing situation; in the processinterview, there were questions about defining problems in implementation and in the follow-up interview, there were questions about assessing the process of implementation.

Data collection procedure involved a time period of 22 weeks and three steps which were preparation before implementation, during implementation and after implementation. In the step of preparation before implementation, throughout a unit, observations and interviews with students were conducted and an appropriate unit in accordance with interdisciplinary approach was designed. This was to reveal the existing situation in the class where implementation was carried out.

Interviews with students were conducted in the library of the school via audio-recorders and data from observations were obtained with the help of cameras. In the scope of the study, journals were used to record observations related to the implementation problems experienced in the process and to collect the necessary information for alterations. Moreover, journals were benefited to control the consistency of information obtained from other data collection tools.

The researcher in this study had two roles. In her first role, she adopted a non-participant observer role throughout four weeks in the "I am learning about my past" unit. In this process, the researcher did not interfere with the activities conducted by the teacher. In the implementation phase, the researcher had a participant observer role. Using the data collected in the identification of the situation, the researcher reviewed the lesson plans of the unit designed according to conceptbased interdisciplinary approach. The researcher was present as a participant observer during the implementation of these plans since she was the one who conducted them.

Qualitative data collected in the study were analyzed with the help of content analysis method. Audio-recordings concerning interviews and camera recordings concerning observations were transcribed and then content analysis was carried out. Transcribed data were coded by reading line-by-line and then themes were emerged by gathering these codes together with inductive approach.

To ensure reliability, data were coded by a second coder. The inter-rater reliability of interview data was found to be $94 \%$ and for observation data, the inter-rater reliability was $94 \%$. (Reliability=Agreement/(Agreement+Disagreement) *100) (Miles \& Huberman, 2002).

\section{Findings}

In this part, findings obtained from the analysis of research data were presented.

Findings Obtained from Student Interviews in Relation to the Effect of Implementations of Concept-Based Interdisciplinary Approach on Teaching-Learning Processes

Codes with regard to analysis of semi-structured interviews (process and follow-up interviews) were categorized under four themes which are "Activities Implemented in Social Studies Course, Skills Gained by Students with the Help of Activities Implemented in Social Studies Course, Courses Associated with Interdisciplinary Connections in Social Studies Course, Benefits of Making Interdisciplinary Connections in Social Studies Course". All these are demonstrated in Table 1: 
Table 1. Themes and Codes Revealed in Student Interviews about Teaching-Learning Processes

\begin{tabular}{|c|c|c|}
\hline Themes & Codes & $f$ \\
\hline \multirow{6}{*}{ Activities Implemented in Social Studies Course } & Being eager to use it in other courses & 14 \\
\hline & Difference from previous activities & 13 \\
\hline & Developing positive attitude & 7 \\
\hline & Learning deeply & 3 \\
\hline & Learning different disciplines at the same time & 3 \\
\hline & Similarity to previous activities & 1 \\
\hline \multirow{5}{*}{$\begin{array}{l}\text { Skills Gained by Students with the Help of Activities Implemented in } \\
\text { Social Studies Course }\end{array}$} & Codes & $f$ \\
\hline & Making research & 9 \\
\hline & Making observation & 7 \\
\hline & Using computers & 2 \\
\hline & Developing handcraft & 1 \\
\hline \multirow{7}{*}{$\begin{array}{l}\text { Courses Associated with Interdisciplinary Connections in Social } \\
\text { Studies Course }\end{array}$} & Codes & $f$ \\
\hline & Mathematics & 11 \\
\hline & Physical Sciences & 11 \\
\hline & Turkish & 8 \\
\hline & Visual Arts & 6 \\
\hline & Music & 4 \\
\hline & English & 1 \\
\hline \multirow{9}{*}{$\begin{array}{l}\text { Benefits of Making Interdisciplinary Connections in Social Studies } \\
\text { Course }\end{array}$} & Codes & $f$ \\
\hline & Using what is learnt in real life & 14 \\
\hline & $\begin{array}{l}\text { Learning information about different disciplines at } \\
\text { the same time }\end{array}$ & 8 \\
\hline & Learning deeply & 7 \\
\hline & Learning new information & 3 \\
\hline & Saving time & 3 \\
\hline & Making reviews & 3 \\
\hline & Increasing academic achievement & 3 \\
\hline & Developing positive attitude toward all courses & 1 \\
\hline
\end{tabular}

Moreover, seven students uttered that these activities provided them to develop positive attitude toward the course, three students said that the activities provided them to learn deeply and three of the students were in the idea that the activities made them to learn information about different disciplines at the same time in a sense that they were different form the previous activities. Only one of the students stated that he/she got bored with painting. All of the students said that they would like these activities to be used in other courses. Some students expressed their opinions as in below:

“...Teacher, I enjoyed in social studies course more. Now, I like social studies course more..."(FS[Female Student]1).

"...Teacher, what you do is better because all courses are mentioned somehow..."(MS[Male Student]1).

“...while preparing a compass, we rubbed the needle to the magnet like this. We both enjoyed and proved our success and also we enjoyed while doing..."(MS4).

Within the theme of Skills Gained by Students with the Help of Activities Implemented in Social Studies Course, nine students mentioned about contributions to making research, seven students talked about benefits for making observations whereas two of them thought that activities contributed to using computers and one of them was in the idea that activities were useful for developing handcraft. Some students' words about the issue as in below:

"... look at the Internet. For drawing sketch, I got help from the Internet..."(MS6).
“...To make observations, for example preparing a compass, we examined like this. We also examined weather conditions. You gave a task which requires us to make observations from Monday to Friday..."

Related to the theme of Courses Associated with Interdisciplinary Connections in Social Studies Course, eleven of the students said that they realized connections between activities and mathematics and physical sciences, eight of them associated activities with Turkish, six students established connections with visual arts, four of them made associations with music and one of the students stated that there were connections with English course. Some students' notions were as in below:

"...Reading in Turkish, we learnt column chart and patterns in mathematics. We added science and technology. We made drawings about weather conditions..." (FS1).

"...Mathematics, Turkish...Social studies course is already there and there is also science...also visual arts and music..."(FS2).

Concerning the theme of Benefits of Making Interdisciplinary Connections in Social Studies Course, eight students talked about benefits for learning information about different disciplines at the same time, seven students mentioned about the fact that there were benefits for learning deeply, five of them emphasized learning new information, three of them thought that the benefits were linked to saving time, another three students stated that benefits were about increasing 
academic achievement and one of them declared that benefits were about developing positive attitude toward all courses. Some of the students pointed out that:

"...We learnt five courses in one hour rather than six hours. For this reason, it is time-saving...." (MS1).

"...for instance we can learn the things that we miss out. We learn better when we focus on other topics while learning a topic. If we do not make activity or experiments in Turkish or in mathematics, then we have a chance to compensate them in social studies course..." (FS2).

"...for example, teacher, we made a lesson and in that lesson, it seems that we learn all topics. Living and nonliving creatures are taught in science course. We learn both social studies and science. For example; teacher, you made a pattern about weather conditions. We learnt both mathematics and social studies. I mean we learn topics related to other courses while learning in a course..."(MS4).

"...lt is better for understanding the lesson. For example, let's imagine that we are drawing a graphic. It is beneficial for mathematics. It is better to make drawings in mathematics. We draw better. When we read in Turkish course, we read better. We read faster..." (FS7).

All students participated in the study expressed that they could use what they learnt in activities prepared in relation to concept-based interdisciplinary instruction in real life. Nine students indicated that they could use what they learnt in finding directions, two of them could use nature human factors, two students could use in discriminating living and non-living creatures, two of them used to draw sketch and one of them could use in exams.

"....For example, if we know about directions and we are lost somewhere, directions could be useful for us..."(FS6).

“...For example, teacher, we see something moving. To decide whether it is living or non-living, we ask some questions..."(FS1).

Findings Obtained from Observation Recordings in Relation to the Teaching-Learning Process

Table 2 presents the findings about interdisciplinary connections obtained from observation recordings in relation to the teaching-learning processes of implementations of concept-based interdisciplinary approach:

Table 2. Findings Obtained from Observation Recordings about Interdisciplinary Connections

\begin{tabular}{|c|c|c|c|c|c|c|c|c|}
\hline $\begin{array}{l}\text { Interdisciplinary } \\
\text { Connections }\end{array}$ & Environment & $\begin{array}{l}\text { Living-non- } \\
\text { living } \\
\text { Creatures }\end{array}$ & $\begin{array}{l}\text { Nature or } \\
\text { Human } \\
\text { Factors }\end{array}$ & Direction & $\begin{array}{l}\text { Weather } \\
\text { condition }\end{array}$ & Climate & Disaster & Total \\
\hline Science & 47 & 21 & 12 & 0 & 13 & 14 & 9 & 116 \\
\hline Turkish & 7 & 0 & 56 & 10 & 7 & 12 & 33 & 125 \\
\hline Mathematics & 2 & 0 & 5 & 0 & 37 & 9 & 17 & 70 \\
\hline Visual Arts & 0 & 0 & 16 & 0 & 3 & 3 & 0 & 22 \\
\hline English & 0 & 0 & 0 & 4 & 0 & 0 & 0 & 4 \\
\hline Music & 0 & 0 & 3 & 0 & 0 & 0 & 0 & 3 \\
\hline Total & 56 & 21 & 92 & 14 & 60 & 38 & 59 & 340 \\
\hline
\end{tabular}

In Table 2, frequencies of interdisciplinary connections established in the process of teaching-learning are illustrated. According to these findings, the concept of environment was associated with science 47 times, with Turkish seven times, with mathematics two times and in total, 56 interdisciplinary connections were made. In the teaching process of concepts of living and non-living creatures, there were 21 interdisciplinary connections with science course. While teaching nature or human factors, there were 12 connections with science course, 56 connections with Turkish, five connections with mathematics, 16 connections with visual arts and three connections with music. That is to say, there were 92 interdisciplinary connections in total. With regard to the teaching process of the concept of direction, there were 14 interdisciplinary connections in total, 10 of them were associated with Turkish and four of them were associated with English. Moreover, in the process of teaching the concept of weather conditions, 13 interdisciplinary connections were made with science course, 7 connections with Turkish, 37 connections with mathematics, three connections with visual arts and in total, there were 60 interdisciplinary connections. As for the concept of climate, there were 38 interdisciplinary connections in total, 14 of them with science, 12 of them with Turkish, nine of them with mathematics and three of them with visual arts. Concerning the concept of disaster, 59 interdisciplinary connections were made of which nine connections with science, 33 connections with Turkish, and 17 connections with mathematics. As understood in Table 2, throughout the unit, connections were made with music and English courses the least and connections were established with Turkish course the most.

\section{Findings Obtained from the Researcher's Journals}

Findings obtained from the researcher's journal about the effects of implementations of concept-based interdisciplinary approach on teaching-learning process: 
1. Implementations of concept-based interdisciplinary approach were observed to contribute such benefits as students' attention to the course, students' eagerness to participate in the course, developing positive attitude toward the course, working collaboratively, decisionmaking and critical thinking. Some expressions about this identification by the researcher are like in below:

"...I observed that they enjoyed and willingly did their tasks in the activities. Moreover, I saw that they were highly motivated. Today, in the second lesson, we examined the features of the environment in the real places when we went to the garden with students. Students enjoyed so much in this activity and this was very informative for them..." (24.12.2013)

"...I observed that students did their tasks comprehendingly, studied topics eagerly and had an enjoyable time in these activities..."(08.01.2014).

"...Students were really interested in the compass when they saw it. Most of them saw a compass for the first time. They were especially active while making the compass. They were confused, asking questions and made effort to reach the outcome. Their excitement could be noticed from their faces..." (21.01.2014).

“...Students were actively participated in the activities. They pointed out that they liked learning with the presentation..."(25.02.2014).

2. The second finding from the researcher's journal is that the researcher emphasized interdisciplinary connections in the first lessons of the unit; however, students started to realize interdisciplinary connections on their own as the lesson progressed. Some of the researcher's expressions about this observation are as in below:

"...It was highlighted for the students that this topic was actually related to science course but it could also be taught/learnt in social studies course..."(24.12.2013)

"...While drawing sketch, it was emphasized that they made use of what they learnt in mathematics and visual arts..." (06.01.2014).

“...Today, we focused on how nature and human factors reflected in our cultural values; for this reason, we made connections with Turkish and music course and students perceived these very well..."(21.01.2014).
"... One of the students found the section about column graphic in mathematics course book and showed that the same topic was also there. I emphasized that topics related to mathematics could take place in social studies course..." (13.02.2014).

"...Numerical data in the given situations attracted their attention. They stated that these numerical data were associated with mathematics course..." (25.02.2014).

Findings Obtained from Students' Journals

According to findings obtained from students' journals, it was revealed that students participated in the courses willingly, they approved the activities and they also enjoyed while performing in these activities. All of the students uttered that they especially liked and enjoyed activities performed in the garden. Furthermore, these findings indicate that students were aware of the concepts taught in the cycles.

"...I learnt how to discriminate nature and human factors. I learnt sketch."(MS5).

"...we enjoyed so much in the garden while making the compass because it was so informative and amusing..."(FS4).

“...we learnt weather conditions. We saw the instruments used for weather forecast. I learnt meteorology. I learnt how to draw weather graphics..." (MS6).

"...there is no activity that I did not like because all activities are so beautiful..."(MS4).

"...we learnt natural disaster and human disaster. We conducted earthquake drill. We learnt what precautions we took in an earthquake..." (MS2).

"...there is no activity that I did not like because everything was so beautiful..."(FS6).

Findings in Relation to Authentic Assessment Process of Implementations of Concept-Based Interdisciplinary Approach

Codes emerged from semi-structured interviews conducted with students in relation to authentic assessment process of implementations of concept-based interdisciplinary approach were gathered under the theme of "Authentic Assessment Process in Social Studies Course". Codes and frequencies linked to this theme were given in Table 3:

Table 3. Themes and Codes Emerged in Students' Interviews in Relation to Authentic Assessment Process

\begin{tabular}{|c|c|c|}
\hline Theme & Codes & $f$ \\
\hline \multirow{7}{*}{ Authentic Assessment Process in Social Studies Course } & Difference from previous activities & 12 \\
\hline & About learning process & 7 \\
\hline & Using metacognitive strategies & 6 \\
\hline & Student-centered & 4 \\
\hline & $\begin{array}{l}\text { Using information about different disciplines at the } \\
\text { same time }\end{array}$ & 4 \\
\hline & Making review & 1 \\
\hline & $\begin{array}{l}\text { Making association between prior and new } \\
\text { knowledge }\end{array}$ & 1 \\
\hline
\end{tabular}


As seen in Table 3, in the theme of Authentic Assessment Process in Social Studies Course, twelve students pointed out that assessment activities performed in social studies course were different from the previous activities, seven students thought that assessment was oriented to learning process, six students stated that they used metacognitive strategies in these activities, four students said that activities were student-centered and four students mentioned that activities required to use information about different disciplines at the same time. One of the students was of the opinion that these activities helped making reviews; one student said that activities provided them to make associations with prior knowledge and another one stated that activities were enjoyable. Some students' views are demonstrated below:

"...You were teaching about natural environment and you gave us that paper. We did the task and we learnt which one we did right and which one we did wrong..."(MS2).

“...Teacher, they were helpful for making reviews, gathering information that we learnt together and for adding what we learnt to our already-existing knowledge..." (FS1).

"...I could understand whether I comprehended the topic or not..." (FS3).

"...What you teach is also related to other courses. We evaluate ourselves in these activities. We can see whether we are at a good, fair or poor level..." (FS2).

Moreover, in his/her journal, the researcher stated that students realized that they enjoyed, were motivated, used their observation skills and they used information about different disciplines at the same time in authentic assessment activities. Expressions linked to this observation of the researcher are as in below:

"...In the authentic assessment task, each student tried to do it on his/her own. I helped them about how they should ask questions in some situations while they were making classifications. They started to realize how they made classifications..." (02.01.2014).

“...Students started to realize interdisciplinary connections on their own. They immediately realized that patterns were the topics of mathematics and they really liked making patterns in social studies course..." (13.02.2014).

\section{Results and Discussion}

Research findings indicate that students found activities prepared according to concept-based interdisciplinary approach as different from the previous activities. These activities provided students to learn information about different disciplines at the same time, to learn deeply, to learn new information, to develop positive attitude toward the course, to increase academic achievement, to save time and to make reviews. Head (1997) pointed out that in interdisciplinary instruction, students actively participated in learning, the curriculum was full of rich, applicable and realistic information and it presented authentic integrations; moreover, with the interdisciplinary unit, students' knowledge increases and students develop positive attitude toward the unit. Mathison and Freeman (1997) argued that interdisciplinary approach has such influences as developing positive attitude toward oneself, increasing motivation, permanent learning and understanding in terms of educational outcomes. On this issue, Vars (2001) pointed out that integrated teaching provided students' self-confidence and desire to learn to increase.

Students had a chance to make concrete observations in activities prepared based on concept-based interdisciplinary approach in real environments out of the class. Furthermore, they needed to make research in order to perform authentic assessment tasks. They participated in an effective learning process by asking questions, thinking critically, making observations and classifications. In this way, students had an opportunity to use so many skills. In that respect, one of the findings is that the implemented activities made students to gain skills such as making research, observation and using computer. Identically, Coşkun and Demirel (2010) stated that an integrated instruction approach had positive effects on students' active use of language, building conceptual connections, transferring what is learnt, problem-solving, using technology effectively and making scientific research. Savage and Drake (2016) reported that the teachers also found the interdisciplinary approach an important approach and had positive ideas about it.

One of the most significant characteristic of interdisciplinary instruction approach is that it presents knowledge in a holistic manner just like in the real life; rather than presenting knowledge by dividing small pieces. This approach based on philosophy of progressivism aims at providing students to have experiences in relation to situations which they can encounter in real life (Ornstein \&,Hunkins, 2004: cited in Coşkun, 2009). Relatedly, another research finding is that the implemented activities helped students to gain knowledge that can be used in real life. Students asserted that they could use what they learnt in real life and this may be an indicator of the fact that the interdisciplinary approach was properly perceived. Yolcu (2013), Yarımca (2010) and Savaş (2006) also emphasized that interdisciplinary studies ensured a holistic point of view without separating the life into pieces, students transferred knowledge into real life circumstances and they could make connections with other courses.

In the study, it was revealed that interdisciplinary connections were established with mathematics, science, Turkish, visual arts, music and English courses in activities implemented in social studies course according to student interviews and observation recordings. With regard to student interviews, there were interdisciplinary connections with science and mathematics the most whereas there were interdisciplinary connections with music and English the least. According to observation findings, there were interdisciplinary connections with Turkish the most whereas there were interdisciplinary connections with music and English the least. Similarly, Yolcu (2013) stated that interdisciplinary projects and performance tasks provided students to realize and use 
interdisciplinary connections in the program. Interdisciplinary teaching is composed of the integration of methods of more than one discipline in order to explain and teach a theme, case or topic. Accordingly, all lessons ranging from physical sciences to art should have a role to play in providing students with comprehensive learning experiences (Smith \& Johnson, 1993).

Whereas the researcher emphasized the interdisciplinary connections in the first lessons, students started to realize the connections on their own and they established new connections as the lessons progressed. In parallel with this finding, according to Gestalt theorists, an individual perceives the whole as a meaningful, unified single unit instead of separating the whole into its pieces. Then, the individual discovers the connections between the whole and its pieces (Senemoğlu, 2009). Erlandson and McVittie (2001) indicated they realized that in integrated curriculum approach, students made connections between the content of the subject and real experiences and all lessons were integrated in the curriculum.

Regarding the findings obtained from the researcher's journal, the activities increased students' interest into the course and contributed to developing positive attitude, working collaboratively, decision-making and critical thinking skills. One of the findings obtained from students' interviews, observation recordings and students' journals is that students participated in the lessons eagerly and they liked the activities and also they enjoyed while performing in these activities. Shriner and others (2010) stated that students could gain much knowledge with this approach and they could relate that knowledge to their real experiences in life. Moreover, they said that learning and teaching process became more joyful for students and teachers with the help of this approach. There are studies supporting these findings in the literature (Aydın \& Balım, 2005; Demirel, Tuncel, Demirhan \& Demir 2008; Savaş, 2006; Simon, 2015; Trent \& Riley, 2009;).

Students understood the elements of interdisciplinary instruction approach in relation to the unit implemented based on concept-based interdisciplinary approach. It can be said that students had mostly positive opinions and attitudes about the elements of this approach. In the light of the research findings, it can be suggested that teachers can enrich the instruction by using these kinds of activities in their lessons. Moreover, it can be possible to involve interdisciplinary activities in course books to increase the quality of the instruction. Students thought that authentic assessment activities used in the assessment process were different from the previous ones. These activities differed from the previous ones in terms of being oriented to the learning process, being student-centered, requiring to use metacognitive strategies and information about different disciplines. Although there were students saying that they had difficulty in some activities in the process of authentic assessment, it was explored that students thought that these activities were more enjoyable, more informative and they would like these activities to be used in other courses. Concordantly, Karakuş (2006) emphasized that students found authentic assessment methods as different from the previous ones and they thought that activities were enjoyable, amusing, informative and more realistic. Students were of the opinion that these methods were better at assessing their knowledge and skills and they were enjoyable and provided effective learning; for this reason, the activities should be used in other courses and units. In that regard, authentic assessment activities and interdisciplinary connections can be included in the assessment of mathematics, Turkish and science courses as well as social studies course.

\section{References}

Aydın, G. \& Balım, A. G. (2005). Yapılandırmacı yaklaşıma göre modellendirilmiş disiplinler arası uygulama: enerji konularının öğretimi [An Interdisciplinary Application Based on Constructivist Approach: Teaching of Energy Topics]. Ankara Üniversitesi Eğitim Bilimleri Fakültesi Dergisi, 38(2), 145-166.

Büyüköztürk, Ş., Çakmak, E.K., Akgün, Ö.E., Karadeniz, Ş. \& Demirel, F. (2011). Bilimsel araştırma yöntemleri [Scientific research methods ]. Ankara: Pegem Akademi.

Coşkun, S. B. (2009). ilköğretim 8. sınıf matematik dersinin disiplinler arası yaklaşımla işlenmesinin öğrencilerin matematik başarıları ve eleştirel düşünme eğilimleri üzerindeki etkisinin incelenmesi [An investıgation of the effect of interdısciplinary approach used at 8th grade math lessons on students' math achievement levels and critical thinking dispositıon inventory] . Yayımlanmamış yüksek lisans tezi, Yıldız Teknik Üniversitesi, İstanbul.

Coşkun, Y.D. \& Demirel, M. (2010). Proje tabanlı öğrenme ile desteklenen disiplinler arası öğretim yaklaşımına ilişkin bir durum çalışması [A case study on interdisciplinary teaching approach supported by project based learning]. Educational Research Association The International Journal of Research in Teacher Education, 2(3), 28-53.

Demir, E. (2009). Illköğretim ikinci sınıflarda uygulanan disiplinler arası bütüncül öğretim yaklaşımının etkisi [The effect of the interdisciplinary holistic teaching approach applied in the second year of primary education]. Yayımlanmamış yüksek lisans tezi, Selçuk Üniversitesi, Konya.

Demirel, Ö. (2011). Eğitimde program geliştirme [Curriculum development in education]. Ankara: Pegem Akademi.

Demirel, Ö., Tuncel, İ., Demirhan, C. \& Demir, K. (2008). Çoklu zeka kuramı ile disiplinler arası yaklaşımı temel alan uygulamalara ilişkin öğretmen ve öğrenci görüşleri [The interdisciplinary approach based on multiple intelligence theory with practice teacher and student views]. Eğitim ve Bilim, 33(147), 14-25.

Doğanay, A., Karakuş, M. \& Bolat, Y. (2013). Sosyal bilgiler dersinde disiplinler arası öğretime yönelik öğretmen görüşleri [Teachers' views about interdisciplinary teaching in social studies course]. II Ulus/ararası Sosyal 
Bilgiler Eğitimi Sempozyumu Tam Metin (s.403-422). 2628 Nisan 2013, Aksaray.

Dupe, C. (2009). Assessment and evaluation practices in outdoor, experiential, environmentally-focused integrated and interdisciplinary programs. Unpublished master's thesis, University of Lakehead, Ontario.

Erlandson, C., \& McVittie, J. (2001). Student voices on integrative curriculum. Middle School Journal, 33(2), 2836.

Hartzler, D. H. (2000). A meta-analysis of studies conducted on integrated curriculum programs and their effects on student achievement. Unpublished doctoral dissertation. University of Indiana, Bloomington (UMI: 9967119).

Head, R. R. (1997). Interdisciplinary curriculum: The effects of a unit about landscapes on second-grade students' knowledge, skills and attitude. Unpublished doctoral dissertation, Universty of Alabama, Alabama (UMI: 9821539).

Jacobs, H. H. (1989). The interdisciplinary models: A step by step approach for developing integrated units of study. H.H. Jacobs (Ed.) In Interdisciplinary Curriculum: Design and Implementation (p. 53-66). USA: ASCD.

Jacobs, H. H.(2004). Step-by-step guide to interdisciplinary curriculum design. Interdisciplinary Learning in Your Classroom, from http://www.thirteen.org/ edonline/ concept2class/ interdisciplinary/ implementation. html\#tpp. Retrieved: 14.09.2012.

Jones, C. (2010). Interdisciplinary approach - advantages, disadvantages, and the future benefits of interdisciplinary studies. ESSAI. 7, 76-81.

Karakuş, F. (2006). Sosyal bilgiler öğretiminde yapı ı öğrenme ve otantik değerlendirme yaklaşımlarının ögrencilerin akademik başarı, kalıcılık ve sosyal bilgiler dersine yönelik tutumlarına etkisi [The effect of constructivist learnıng and authentıc assessment approach on social studies teachıng students' academic achievement retention and attıtudes towards social studies]. Unpublished Doctoral Dissertation, Çukurova Üniversitesi, Adana, Turkey.

Keçe, M. \& Merey, Z. (2011). illköğretim sosyal bilgiler kazanımlarının sosyal bilimler disiplinlerine ve disiplinler arası anlayışa uygunluğunun belirlenmesi [Determination of suitability of objectives of elementary social studies to social science disciplines and to interdisciplinary mentality]. Yüzüncü $Y_{I I}$ Üniversitesi, Eğitim Fakültesi Dergisi, VIII(I), 110-139.

Kutlu, Ö., Doğan, C.D. \& Karakaya, İ. (2010). Öğrenci başarısının değerlendirilmesi. Performansa ve portfolyoya dayalı durum belirleme [Evaluation of student achievement. Performance and portfoliobased situation determination]. Ankara: Pegem Akademi.

Mathison, S. \& Freeman, M. (1997). The Logic of Interdisciplinary Studies. The paper presented the Annual Meeting of the American Educational Research Association, Chicago.
Milli Eğitim Bakanlığı, (2009). ilköğretim 4. ve 5. Sınıflar sosyal bilgiler dersi öğretim programı ve kılavuzu [Primary education 4th and 5th classes social sciences course curriculum and guide]. Millî Eğitim Bakanlığı, Talim ve Terbiye Kurulu Başkanlığı.

Miles M. B. \& Huberman A. M. (2002) Qualitative researcher's companion. London: Sage Publication.

Özkök, A. (2005). Disiplinler arası yaklaşıma dayalı yaratıcı problem çözme öğretim programının yaratıcı problem çözme becerisine etkisi [Effects of interdisciplinary creative problem solving teaching program on creative problem solving skills]. Hacettepe Üniversitesi Eğitim Fakültesi Dergisi 28, 159-167.

Savage, \& Drake (2016). Living transdisciplinary curriculum: teachers' experiences with the international baccalaureate's primary years programme. International Electronic Journal of Elementary Education, September 2016, 9(1), 1-20."

Savaş, B. (2006). Illköğretim 4. Sınıfta bütünleştirilmiş ünite ve yapılandırmacı yaklaşımın öğrencilerin öğrenme düzeylerine, öğrenmeye karşı tutumlarına, akademik özgüvenlerine etkisi [Influence of unit and constructivist approach integrated in elementary school 4 to students' learning levels, attitudes towards learning, academic self-confidence]. Unpublished Doctoral Dissertation, Dokuz Eylül Üniversitesi, İzmir.

Senemoğlu, N. (2009). Gelişim öğrenme ve öğretim [Development, learning and teaching]. Ankara: Pegem Akademi.

Shriner, M., Schlee, B., \& Libler, R. (2010). Teachers' perceptions, attitudes and beliefs regarding curriculum integration. The Australian Educational Researcher, 37(1), 51-62.

Smith, J.L. \& Johnson,H. (1993). Interdisciplinary thematic literature studies. Language Arts Journal of Michigan, 9(1), 54-67.

Simon, C. E. (2015). Effects of interdisciplinary experiential pedagogy on elementary social studies. Unpublished master's thesis, The Faculty of the Kalmanovitz School of Education, Saint Mary's College of California.

Tynjälä, P. (1999). Towards expert knowledge? A comparison between a contructivist and a traditional learning environment in university. International Journal of Educational Research, 31(5), 357- 442.

Trent, A. \& Riley, J.A. (2009). Re-Placing the arts in elementary school curricula: An interdisciplinary, collaborative action research project. Perspectives on Urban Education, 6(2), 14-28.

Ulusoy, G. (2007) Değişim Cağında Yüksek Öğretim: Global Trendler [Higher Education in Change: Global Trends] .C. A.Coşkun (Ed.) In Paradigm Orientations (s.389-398). İzmir: Yaşar Üniversitesi.

Vars, G. (2001). Can curriculum integration survive in an era of high-stakes testing? Middle School Journal, 33(2), 7-17. 
Wiggins, G. (1990). The case for authentic assessment. Practical Assessment Research \& Evaluation, 2(2).

Yarımca, Ö. (2010). Illköğretim II. kademe görsel sanatlar dersinde disiplinler arası yaklaşıma dayalı uygulamalar [Applications based on interdisciplinary approach in the course "visual arts" of primary education, II. stage]. Unpublished Doctoral Dissertation, Selçuk Üniversitesi, Konya.

Yıldırım, A. \& Şimşek, H. (2005). Sosyal bilimlerde nitel araştırma yöntemleri [Qualitative research methods in the social sciences]. Ankara: Seçkin Yayıncılık.

Yolcu, F. A. (2013). Iilköğretim düzeyinde performans görevi ve proje uygulamaları sürecinde disiplinler arası yaklaşımın etkililiği üzerine bir çalışma [A study on the effectiveness of the interdisciplinary approach in the process of performance task and project implementation at primary level]. Unpublished Doctoral Dissertation, Hacettepe Üniversitesi, Ankara. 
This page is intentionally left blank www.iejee.com 